brary-a checklist of over fourteen hundred titles on time and time telling. The first edition of "Horological Books and Pamphlets," published in 1956, indexed some one thousand words from the horological library. In the intervening years, the collection has grown nearly 50 per cent and ranks as one of the finest of its kind in the United States. The present list covers 109 pages in an $8 \times 11^{\prime \prime}$ format and is available in two editions. The hardbound library edition sells for $\$ 8$ plus $50 \notin$ for shipping and handling. The soft cover edition sells for $\$ 4$ plus $30 \%$ for shipping and handling. Orders should be sent care of The Franklin Institute Library, 20th and the Parkway, Philadelphia, Pa. 19103.

- The Maryland Historical Society announces publication of The Manuscript Collections of the Maryland Historical Society, the first analytical list of the society's more than seventeen hundred collections (375p). The publication is available in July, and is priced at $\$ 15$. Orders should be addressed to P. William Filby, librarian of the society, 201 West Monument Street, Baltimore 21201 but payment should NOT be sent until requested.

- Mansell Information/Publishing Limited is establishing a print run for The National Union Catalog, Pre-1956 Imprints that, according to present plans, will be maintained throughout the ten-year publishing period for the 610 estimated volumes. Many librarians all over the world know that the British $\mathrm{Mu}$ seum Catalogue of Printed Books was sold out before publication was completed. It is hoped that librarians will now make known their needs for this catalog so that they will not be disappointed after publication has begun. Mansell has reserved for each research library a copy of it ninety-six-page Prospectus which contains a full history and description of the catalog, particulars of its publication, and a representative sequence of specimen pages. A copy will be sent on receipt of the library's order or a request for the Prospectus. Terms and conditions of subscription can be obtained from Mansell, 360 North Michigan Avenue, Chicago, 60601, or in London from 3 Bloomsbury Place, WC1.

- The Purdue University libraries systems development unit has announced the completion of the Purdue libraries' computer-produced serials book catalog. The twelve hundred page computer-printout catalog will replace Purdue's 60 -drawer serials card catalog of sixty thousand $3 \times 5$ cards. Copies of the catalog are being distributed to various locations on the Purdue campus. Published in book form, it will be available for off-campus sale. The cata- log can be updated by the frequent production of supplements or by the replacement of the entire printout. At present, it contains thirty thousand serial titles and ten thousand cross references.

- Reference, a Programmed Instruction, published by the Ohio Library Foundation on July 1, was written by Donald J. Sager for para-professional workshops conducted in 1967 by the State Library of Ohio and the Ohio Library Association. 1-10 copies are $\$ 4.50$ each; other scheduled prices and further information should be requested from the foundation, Suite 400,40 South Third St., Columbus, Ohio 43215 .

- The second annual report of the North Riding Record Office, Yorkshire, England, has just been published. This illustrated booklet contains lists of archives deposited during the year 1967, and articles on poor law administration in Guisborough, the Guisborough Grammar School Archive, the Wyvill of Constable Burton Archive, and sources of railway and canal history in the record office. It is obtainable from the County Archivist, North Riding Record Office, County Hall, Northallerton, Yorkshire, England. Price $\$ 1$, including postage. The first report of this record office is still available and contains similar lists for 1966 and articles on ironstone mining at Kirkleatham, the Beresford-Peirse Archive, and the records of the Richmond Monthly Meeting of the Society of Friends. Price 50 cents, including postage.

\section{DOWNS AWARD ANNOUNCED}

An award for the outstanding contribution to intellectual freedom in libraries has been established in honor of Robert B. Downs, University of Illinois dean of library administration. Announcement of the award was made on May 24 at a dinner honoring Dean and Mrs. Downs for his twenty-five years of service to the university, given by the graduate school of library science faculty and their spouses. Lyle H. Lanier, U. of I. executive vice president and provost, paid tribute to Downs. Prof. Herbert Goldhor, director of the library school, announced the award.

The award will consist of $\$ 500$ and a citation. Nominations will be sought and accepted from any source. The basis of the award may be any type of action, such as a publication, successful or unsuccessful opposition to censorship, or a research study-whether at one time or over a period of time. It will not be given more often than once a year. 